\title{
The Evolution and Implications of Boundary Work
}

The previous chapter analyzed five types of boundaries that middle class Pentecostals draw upon in order to negotiate the (in)appropriateness of their religious practice. This boundary work leads to the emergence of a new type of Pentecostalism that is more socially acceptable and decreases tensions with the representations of the middle class. This section will discuss the historical origins of this type of Pentecostalism and the implications of the boundary work of middle class Pentecostals.

Historically, middle class Pentecostalism has its origins in the upward social mobility of sections of the Pentecostal movement as well as in the Pentecostalization of middle class evangelicals. The first section will briefly describe these developments, which culminate in a tendency towards a Pentecostalism that is more adapted to the middle class representations.

The emergence of this new type of Pentecostalism is based on boundaries drawn in opposition to other Pentecostals. This boundary work not only produces a more "appropriate" type of Pentecostalism, but also implies the (re) production of an imaginary of an inappropriate other from which the "decent" middle class seeks distinction. The second section addresses the question of how middle class Pentecostals relate to this "inappropriate other".

Despite endeavors to craft a more appropriate Pentecostalism, to a certain extent, deviations, tensions, and inappropriateness remain. The lingering inappropriateness of the appropriate form of Pentecostalism will be tackled in the third section.

\section{1}

\section{The Evolution of an Appropriate Pentecostalism}

Pentecostalism stands in tension with the social representations of the educated middle class of the "European" metropolis of Buenos Aires. Trembling in ecstasy, shouting loudly, bursting into tears, singing and dancing to cumbia, praying vehemently in tongues - an educated middle class Porteño could not be in a less fitting place. As an accumulation and recombination of elements of popular Latin American culture, Pentecostalism not only has few cultural connections to the educated middle class, it also represents a culture from which the educated middle class seeks distinction. The tensions that arise from the mismatch between the middle class representations and Pentecostalism, exert

(C) JENS KOEHRSEN, 2016 | DOI 10.1163/9789004310148_010

This is an open access chapter distributed under the terms of the Creative Commons Attribution-

Noncommercial 3.o Unported (CC-BY-NC 3.0) License. 
a pressure to convert Pentecostalism into a more tolerable religious option for the educated middle class. As a result, a socially more adapted style of Pentecostalism differing from that of "mass Pentecostalism" emerges. Historically, its emergence is the consequence of three different developments: (1) upward social mobility among second and third generation Pentecostals; (2) the spiritual avivamiento among evangelical communities with a middle class tendency; and (3) religious "market forces" discovering new clientele for Pentecostalism in the urban middle class. In the following paragraphs, I will describe these three developments.

\subsubsection{Upward Social Mobility}

Many second and third generation Pentecostals experienced upward social mobility and adapted their cultural preferences to their new class environment. The old-fashioned style of "lower class Pentecostalism" ceased to be an appropriate cultural model for them. Consequently, they tried to adapt Pentecostalism to their "new" class representations. These changes often took place in older, established churches and were accompanied by conflicts.

One example of this process is the historical evolution of Assembly of Christ's religious style. As described above, AC experienced a change in its social composition towards becoming a middle class church. This also included a change in its religious style, when its church services went through a process of dePentecostalization. Powerful spiritual practices disappeared more and more from the public scene of the church service and were substituted by a focus on the sermon and education. ${ }^{1}$ AC became a more acceptable and presentable option for its growing middle class membership, who did not want to feel ashamed of being Pentecostal when bringing non-Pentecostal friends to the church.

Thus, the evolution of a new, more socially-adapted style within the church appears also to be the result of the perceived risk of being thrown into one bucket with the "uncivilized" lower class, and being conceived of as an "inappropriate other" by middle class peers. Their middle class status is thus endangered. Facing this risk, the development of a more "appropriate" style of Pentecostalism allows them to confirm their middle class identity and decrease the tension between the middle class representations and their religious affiliation.

1 Interestingly, the style of middle class Pentecostalism appears to move towards historical Protestantism. However, it does not become historical Protestantism, but rather forms a mix between the more secularized and rationalized style of historical Protestantism and the style of "mass Pentecostalism". 
This process has frequently been described by scholars of religion in terms of the sect-church dichotomy. ${ }^{2}$ Sects are conceived of as standing in a tense relationship with their social environment: they tend to reject the surrounding society and to be rejected by the society. Further, sects are thought to attract particularly lower class individuals, ${ }^{3}$ whereas middle class actors are less likely to affiliate with sects due to the stigma and social costs involved in sectmembership. ${ }^{4}$ However, over time, sect members may experience socialupward mobility. In order to reduce the stigma and social costs of their religious membership, they will decrease the level of tension between their religious group and the surrounding society. As such, the religious group adapts more and more to the general social standards. In this way, the process of social upward mobility finally transforms the sect into a church. Unlike the sect, the church is characterized by a higher acceptance of the social environment and an increased public legitimacy. Many middle class Pentecostals seem to experience such a process: they assume enhanced social positions in which formal behavior in the public sphere and the hiding of inappropriate practices become increasingly important. ${ }^{5}$ Sect-type practices would create enhanced tension with the social environment and impose significant social costs on these middle class actors. Hence, a church-type model of Pentecostalism, which reduces the tensions with the social environment, is more convenient. Therefore, middle class Pentecostals seek to establish their congregations as churches. They break away from the sect-model by banning socially inappropriate practices and pursuing public legitimacy. ${ }^{6}$

The development towards a more church-type style of Pentecostalism can also be described as a three-fold process of rationalization, secularization and institutionalization. According to Gorski, rationalization and secularization of religion refer to a process in which religion becomes less magical and experimental, and more ethical and intellectual. ${ }^{7}$ The partial ban on spiritual intervention practices and expressive elements, as well as the increased emphasis on intellectual practices - sermons and Bible interpretation - and ethics in the

2 Iannaccone 1988, 1994; Niebuhr 1929; Troeltsch 1923/1977.

3 Niebuhr 1929: 25; Pyle 2006: 78.

4 Iannaccone 1994.

5 Lahire distinguishes between "marchés francs" and "marchés tendu": "Les marchés tendus imposent de la mise en forme, de la préparation, du calcul, de l'attention, du soin, du souci, etc." (Lahire 2004/2006:632) He states that the difference between lower and higher social classes is that the latter are more frequently involved in the "marchés tendus". See Lahire 2004/2006: 632 .

6 See also Corten 1995: 189-192, 209-215.

7 Gorski 200o: 148-149. 
"appropriate" style of Pentecostalism, are evidences for such a rationalization and secularization process within middle class Pentecostalism. ${ }^{8}$ Moreover, the involvement of umbrella organizations and educational institutions indicate an institutionalization process, implying that Pentecostalism loses its sectarian appearance and is converted into a church-type Pentecostalism. ${ }^{9}$

\subsubsection{The Pentecostal Avivamiento among Non-Pentecostal Evangelicals}

The upward social mobility of second and third generation Pentecostals is not solely responsible for the emergence of an "appropriate" style of Pentecostalism. Simultaneously, sectors of the non-Pentecostal evangelical community that likewise exhibit middle class tendencies have experienced a spiritual avivamiento. In particular, members of Baptist congregations and the Plymouth Brethren at one time experimented with the new Pentecostal expressions, which were often not welcomed by the spiritual leaders of these congregations. Therefore, many of the "Pentecostalized" members of these churches switched to Pentecostal congregations. Others founded their own charismatic communities, like the Comunidad Cristiana or Iglesia Puerta Abierta. Today, these two churches are charismatic congregations with a strong middle class membership. They exhibit a religious style similar to that of the long-standing Pentecostal congregations, who experienced a change in their social composition into a more middle class base. For this reason, the "appropriate" style of Pentecostalism can be seen to have been created basically from two sides: (1) from Pentecostal churches that increasingly assumed a middle class profile and (2) from previously non-Pentecostal Protestants, who already had a strong middle class influence and experienced a charismatic renewal.

Both developments - the partial de-Pentecostalization of Pentecostal churches and the Pentecostalization of some evangelical communities culminate in a similar religious style. They form a milder type of Pentecostalism

8 These processes take hold within the public sphere of the church, even though it is unclear to what degree they effect the private practice. The inappropriate, socially non-conforming elements are eliminated from the public sphere of the church service and are partially transferred to the private sphere. The extent to which processes such as secularization are also taking place in the private religious sphere is unclear. Maybe the process of secularization and rationalization of public religious practice precedes secularization within the private sphere - embracing the private practice and popular religious beliefs - of middle class Pentecostals. Yet, based on the existing insights, it is impossible to assess and predict such a change.

9 As such, the secularization process of the religious group implies an adaptation to the external social environment and its values (Luca 2008b: 40). General secularization trends in society may also affect religious organizations and drive them to secularize internally. See, for instance, Dobbelaere 2002: 123-130. 
and create boundaries in opposition to "lower class" Pentecostalism. A partially de-Pentecostalized style of Pentecostalism emerges, which constitutes a combination of popular mass Pentecostalism and the middle class representations.

\subsubsection{Pentecostal Entrepreneurship: The Middle Class as a New Religious Market Niche}

The new, socially adapted, and more softly charismatic style of Pentecostalism which is performed in nice, tidy churches in middle class neighborhoods, decreases the threshold for other middle class Argentineans to become Pentecostal. Pentecostal entrepreneurs, aware of the preferences and aspirations of the urban middle class, engage in fishing for this new clientele by adapting their church styles. In this way, religious "market forces" spur a further adaptation to the representations of a new and, thus far, widely ignored religious clientele: the urban middle class. Despite enjoying the reputation of being a particularly difficult clientele to convert, due to its supposed secularity, this social segment is actively pursued by some churches, by carrying out evangelizing campaigns in middle class neighborhoods and adopting new religious styles, considered more fitting with the urban middle class. One example is the church Cristo la Solución located in the neighborhood of Flores.

Cristo La Solución is one of the most ancient churches in Buenos Aires city and, with almost one thousand active members, is one of the largest churches in the urban district of Flores. Due to the extensive use of modern media such as TV-programs, radio and internet, and evangelization events in affluent parts of the city of Buenos Aires such as Puerto Madero, the church is well-known among Pentecostals. Today, the church's marketing strategies target the urban middle class in particular. In order to recruit new members, Cristo La Solución applies marketing strategies involving the aesthetics and values of the middle class. It uses modern stylish designs on flyers, its homepage, and its own decoration. Despite its efforts to attract the urban middle class, the church remains very mixed with regard to its social composition and especially appears to attract the lower middle and lower classes. With its modern image and targeted offers such as hip-hop dance, youth holidays, etc., the congregation particularly attracts youths. More important than the marketing efforts of the church are the changes in the religious practice. Informants reported to me that the church once embraced a ministry dedicated to the expulsion of evil spirits. Faith healing and exorcisms were frequent and important elements of the religious practice. With 
the church tending more toward the middle class, faith healing and exorcism disappeared. Finally, the ministry for exorcism was abandoned and faith healing and exorcisms were banned from the official practice. Today, the performance of such practices is limited to the laying on of hands at the end of the service. This practice is performed in a quite atmosphere. Demonic manifestations do not occur and the pastor or his usher only briefly put their hand on the forehead of the participant. The new attitude towards these healing practices is illustrated by the following scene, which I observed during a service: a middle aged woman manifested loudly at the beginning of the church service. She was crying and shouting - a behavior that would have been interpreted as a form of demonic possession by GIL pastors and would probably have led to the conducting of an exorcism. This however was not the form considered appropriate in Cristo La Solución. At first, the worship was continued, ignoring her in the hope that she would stop. But the woman continued and many members looked irritated and disturbed by her comportment. The continuation of the church service was unthinkable. Thus, a church leader asked a group of ushers to take the women out of the hall. She was accompanied to a different part of the church building, where she could no longer disturb the service. Her behavior was not integrated into the church service, as an exorcism no longer had any place.

Faith healing and spiritual warfare are today substituted by a new form of healing strategy: personality change through coaching. The sermons of the pastor of the congregation, pastor Juan Crudo, frequently resemble a coaching workshop, in which he tries to empower his audience with proactive messages. The stated objective is to change the attitude of the devotee. This work is continued in small church groups where leaders accentuate the message and empower members. Moreover, in the church's bookstore, visitors can buy a wide variety of Christian self-help literature written by the pastor. These publications concern different areas of life such as financial prosperity, debt, happiness, professional success, and family. Besides these empowerment strategies, the congregation also engages in a discourse on miracles. The notion of miracles, however, is not as pronounced as in other Pentecostal churches and is frequently connected to the concept of prosperity gospel. This becomes evident during the offering and tithing, in which the pastor stresses the concept of sowing and harvesting: devotees who give will later receive a hundred or even a thousand times what they gave. Thus, the belief in supernatural intervention plays an important role in the discourses of the church. The practice of Cristo La Solución constitutes a mix between 
empowerment strategies and the search for favorable supernatural interventions. Although the church abandoned practices that could alienate the middle class, at the same time it maintained practices and discourses that may be regarded critically by the middle class such as the discourse of prosperity gospel. Cristo La Solución combines a "mainstream" Pentecostalism with a style of Pentecostalism more adapted to the urban middle class. Thus, the style in which this recombination results is still somewhat different from the "appropriate" style of Pentecostalism described in this study.

The example of Cristo La Solución reveals that Pentecostal churches may pursue strategies to attract the middle class and therefore partially adapt their style to what this clientele values. However, the degree to which these strategies and adaptations are successful is questionable, since the vast majority of members in churches like Cristo La Solución are still recruited from the lower class. This may be due to the fact that, to a certain extent, the church styles still remain attached to characteristics that are regarded critically by middle class Pentecostals, such as the undisguised employment of prosperity gospel in Cristo La Solución.

Furthermore, the case of Cristo La Solución illustrates that aspects of the "appropriate" style of Pentecostalism can also be appealing to lower class Pentecostals. Nor is the taste for the "appropriate" style of Pentecostalism an exclusively middle class phenomenon. Although the emergence of a socially more adapted style of Pentecostalism is particularly related to the involvement of middle class actors in Pentecostalism, there are also segments of lower class Pentecostals that practice this style of Pentecostalism by recombining, for instance, some of its elements with other styles of Pentecostalism. ${ }^{10}$

\subsubsection{Crafting Publicly Visible Boundaries - An Outlook}

Middle class Pentecostalism has been promoted by the three developments described in the previous paragraphs. These developments culminate in more appropriate tastes and styles of Pentecostalism. By drawing boundaries in opposition to the inappropriate attributes of Pentecostalism, middle class Pentecostals negotiate the (in)appropriateness of their religious belonging.

10 The tendency towards a more socially acceptable style of Pentecostalism is not an exclusively middle class tendency. Also, lower class Pentecostals may prefer this style and promote it. In these cases, they may reject, for instance, an excessively loud style of Pentecostalism or adapt to the "civilization discourse" by cleansing Pentecostalism of some of its "uncivilized" characteristics. 
Nevertheless, the boundaries are still rather fragmented and only visible to those who have experimented with Argentinean Pentecostalism. A process of social institutionalization that would render the distinction between "appropriate" and "inappropriate" forms of Pentecostalism publicly visible has, so far, barely emerged. However, such a public institutionalization of this distinction would allow middle class Pentecostals to publicly display the appropriateness of their religious belonging and reduce social tensions. In this case, non-Pentecostal class peers would be able to directly recognize middle class Pentecostals as belonging to a more appropriate form of Pentecostalism, instead of throwing them into one category with the "inappropriate" lower class Pentecostals.

For this reason, in the long run, middle class Pentecostals might seek to establish publicly visible boundaries between appropriate and inappropriate forms of Pentecostalism. They may endeavor to transform the, thus far, fragmented symbolic boundaries into institutionalized, publicly visible boundaries which differentiate between the "high art" of Pentecostalism - a decent, middle class Pentecostalism that is recognized by society as an appropriate form of religion - and mass-Pentecostalism, which corresponds to the Pentecostalism of the popular masses residing in the lower class neighborhoods and slums of Argentina. There seems to be some efforts in this direction. The struggles for political and public recognition that are fought by evangelical umbrella organizations, point to the attempt to establish a public image of an appropriate Pentecostalism..$^{11}$ The exclusion of highly visible, inappropriate churches from these umbrella organizations, such as the IURD and the church of Pastor Gimenez, contributes to these attempts to create a public image of an appropriate Pentecostalism that distinguishes itself from the "inappropriate" manifestations of Pentecostalism. However, only time will tell whether, and to what extent, these efforts yield results, and whether a publicly visible representation of a distinguished form of Pentecostalism - a respectable, appropriate Pentecostalism - will emerge and convert the fragmented symbolic boundaries into publicly visible, "objective" boundaries.

\subsection{The Inappropriate Other}

The creation of distinctions is based on an imagined inappropriate other. By drawing symbolic boundaries, middle class Pentecostals create and reproduce the imaginary of an inappropriate other, a Pentecostal who embodies the

11 See, for instance, Wynarczyk 2009a, 2010. 
characteristics of Pentecostalism that do not fit into middle class representations. The inappropriate other is not necessarily a Pentecostal from the lower class, but both - the inappropriate Pentecostal and the lower class Pentecostal are often grouped together for middle class Pentecostals. As such, the inappropriate other becomes particularly manifest in the Pentecostal churches located in the lower class suburbs of Greater Buenos Aires. These churches are portrayed as noisy and untidy places, in which uneducated pastors encourage their deprived members to perform silly religious practices.

The comments below from an interview with Marta summarize, to some degree, the attitudes of middle class Pentecostals towards these churches. Her comments refer to a video in which a pastor performs faith healing practices. In this video, the pastor prays vehemently in order to convert cheap dental fillings into silver or gold. During this prayer, the pastor shouts loudly and the audience puts their hands on their mouths. While watching the video, Marta laughs loudly and says:

(...) it seems crazy to me. (...) They may call themselves evangelical communities, but they are outside of what the Word of God is, of what the true doctrine is, and they are completely distorting it, just like a path of salt, or I don't know, or all of this, like selling oil. But notice that all the church's walls are falling apart, meaning, it's in a poor neighborhood, where unfortunately, thanks to a lack of education, anything can happen. And these are environments where people leave their tithes and offerings, but they are not growing spiritually, rather quite the opposite. Here you see that the person is expecting a miracle. There is someone selling miracles, and well, I think this type of community is a very negative thing. That's why I consider education to be fundamental, more than the person who is in charge of a church. This is what I believe is negative about Pentecostalism: the fact that it gives authority to these types of people.

INTERVIEW MARTA PART 2

Marta condemns what she sees in the video, which she describes as the practice of an excess of authority and a manipulation of the audience. Moreover, she stresses the fact that this church is a lower class church. In such humble places, she argues, anything can happen due to a lack of culture. According to her, people approach these churches in search of miracles, while the pastor assumes the role of a seller of miracles who is paid by his clients with offerings and tithes. Due to their focus on miracles, she supposes, members of this church neither seek nor achieve any spiritual growth. She regards this church as similar to the IURD and states that churches like this deviate from the sana 
doctrina. Finally, she mentions that the pastor's education is essential to prevent this type of deviation and abuse.

Her position summarizes the way in which many middle class Pentecostals perceive "lower class" Pentecostalism. The type of spiritual practice to which Marta refers is regarded as a deviation from what is perceived as appropriate as good taste - by middle class interviewees. They disapprove of this form of Pentecostalism as a manipulative excess of authority, a lack of education and spiritual growth, and an abusive deviation from what they call the sana doctrina. Lower class Pentecostals are conceptualized as lacking the necessary education for appropriately judging religious practice. Pablo puts it in simple words:

It is for ignorant people, those who can believe in all this, people who are needy, who have problems and think that they will find solutions here.

INTERVIEW PABLO PART 2

Pablo believes that this type of Pentecostalism is for ignorant people who are suffering from problems. Interestingly, middle class Pentecostals employ the deprivation discourse about Pentecostalism - which explains the success of Pentecostalism among lower classes by referring to the concept of deprivation in order to disqualify other types of Pentecostalism. This type of Pentecostalism, which emphasizes miracles and faith healing, is described as a product of the needs and ignorance of its devotees. Deprivation and ignorance - by themselves already inappropriate characteristics - are believed to lead to an inappropriate, superstitious Pentecostalism.

Attributing "inappropriate" characteristics frequently associated with Pentecostalism to an inappropriate, distant other enables middle class Pentecostals to hold themselves at a distance from these unwanted characteristics of Pentecostalism, characteristics that do not fit well with middle class representations. In this way, they can portray themselves as part of a different type of Pentecostalism, an educated Pentecostalism which has, if it all, only a very distant relationship to the inappropriate other, the ignorant Pentecostal in the poor conurbano.

However, in some cases the inappropriate other is not a distant other, but a very close one, as in the case of Javier. Javier is a member of a church he considers as a church for the villero (slum dweller). Despite being one of the interviewees with the closest relationship to "lower class Pentecostalism," he manifests some of the most critical attitudes. During the interview, he strongly criticizes the style of his church. In fact, it appears to be less his free choice and preferences than the pressure from his family that keeps him in the church. 
In the interview, he seeks to distinguish himself very clearly from his fellow church members and the "Pentecostalism of the villero". He describes the cultural background of his fellow members - which he perceives as very different from his own - as a problem.

(...) it so happens that we come from European roots, from European culture, and this is a church that is really for slum people, for negros - I don't mean to discriminate - so there are things that shock us sometimes, behaviors that - perhaps the slum people are very disorganized, they have a very chaotic way of being, that we don't like, and when you belong to a community like that, it's like they impose it. We, as Europeans, feel discriminated against. It's very difficult to make friendships, because it's like the slum person doesn't have the same level of culture that we do.

INTERVIEW JAVIER

Javier defines himself as European and describes the villero ("slum dweller") as "improvisado" and of a different cultural level. His proximity to "lower class Pentecostalism" appears to produce the need for distinction, a distinction from the culture of the villero. Javier draws clear boundaries between his cultural background and that of the villeros affiliated with the church. By distinguishing himself from this culture, he reasserts his "European" middle class identity. His boundary work reflects the representations of the middle class: he portrays the middle class as European and civilized in contrast to the non-European "negro" from the lower class, who lives predominantly in the lower class surroundings of Buenos Aires and lacks an appropriate culture. ${ }^{12}$ His church appears to him as a manifestation of the "culture of the negro". His malaise is nourished by the perceived conflict between the "culture of the negro" and the social position in which he regards himself: the position of a European middle class individual. As such, he feels compelled to defend the values that the middle class representations embrace: civilized behavior, order, education, etc. Since the church is populated by "negros" who impose their culture on the church, he feels trapped in a religious style that he cannot support from the viewpoint of the middle class. His inability to change the situation nurtures his need to strongly distinguish himself from this type of Pentecostalism. Communicating a clear (dis-)taste is the only way left to delineate his class allegiance.

12 These concepts can be traced back to the modernization discourses in the history of Argentina. See Adamovsky 2009 and Svampa 1994. 


\subsubsection{The Anti-sect Discourse among Middle Class Pentecostals: The Case of the IURD}

In other cases, the inappropriate other becomes associated with concepts related to the anti-sect discourse. Some ideas of the anti-sect discourse that stigmatize the new religious movements in Argentina, reappear in the reasoning of middle class Pentecostals. They are now attributed to other, mainly lower class Pentecostal churches, frequently described as manipulating and exploiting their members. With this communication pattern in mind, middle class Pentecostals can underline their distinctiveness. This, for instance, is the case with the Iglesia Universal del Reino de Dios (IURD). ${ }^{13}$ The TV programs of the IURD and the presence of numerous temples in Buenos Aires lead to a high degree of public visibility for this church. Because of this visibility, middle class Pentecostals are afraid of being equated with the IURD and its questionable practices. For this reason, middle class Pentecostals engage in distancing themselves from the IURD, as is the case with Andrea. Thus far, although Andrea has only seen the IURD church services on TV, she strongly dislikes the church and describes it as a sect that tries to exploit its members. According to her, members of this church only seek worldly prosperity without committing themselves to God's plans:

I would consider the Universal Church to be a cult that has really grown in Argentina and preaches a fantasy gospel, not a practical gospel. I have talked to a lot of people who go to the universal church (...) who are only after economic prosperity, health, to resolve family problems, to find an instantaneous solution to everything, with water or prayer by the pastor, but without making any real effort themselves. They don't understand and don't want to make an effort to forgive or to change their lives and follow the principles of Christ.

INTERVIEW ANDREA

The IURD is the church least liked by the middle class interviewees of the sample. When asked about a church they would never join, all middle class informants mentioned the IURD. The church is highly criticized by middle class Pentecostals and represents many of their dislikes. The style of the church

13 The IURD has a negative image among the Argentinean public. The church puts a strong emphasis on the devil and evil spirits that are supposed to cause different types of suffering. For the Iglesia Universal Reino de Dios (IURD) in Argentina, see Semán 2003; Semán and Moreira 1998; Semán and Oro 2000; for the IURD in general, Corten et al. 2003; Freston 1995: 129-132; 1999: 153-160; Luca 2008b: 230-236, 248-251; Ruuth 2001. 
forms the antithesis of "good taste"; it embodies the anti-taste of the middle class.

The IURD is frequently described as an institution that economically exploits its members and is therefore not considered to be a church, but rather a business primarily interested in economic gain. This alleged economic exploitation was the most prevalent criticism in interviews. For example, Miguel articulates allegations of this nature:

(...) I would never even step onto the sidewalk of the Brazilian Universal Church, for example. It's something that I am totally against, and I would never go into that church. I do not consider them to be Evangelicals; it's something I reject spiritually. (...) They aren't Evangelicals, they aren't Christians, they only want to make money. (...) And they do things...their services create...they have satanic influences. A lot of the things they do are satanic.

INTERVIEW MIGUEL PART 2

Miguel's description of the church as not only a business but also satanic is probably the harshest criticism that a Pentecostal can raise with regard to another Christian church. Other disparagements describe the church as manipulative, and criticize the use of "holy" objects and the absence of the sana doctrina. Finally, the fact that the IURD is not affiliated with an umbrella organization that could supervise its practices is condemned by another interviewee, Eduardo:

...the Universal Church, which is not Christianity at all. It's a sect (...) they are not part of any kind of church umbrella organization; they are not regulated in any way. Because I believe that the church has to be in one... it can't be independent from everything else, it has to be in a community with other churches so that, mutually, there is a certain amount of supervision, so to speak.

INTERVIEW EDUARDO

Claiming that churches should be subject to the supervision of a central organization, Eduardo believes this control mechanism is absent in the case of the IURD.

In fact, the IURD has been trying for several years to join one of the evangelical umbrella organizations and improve its status. ACIERA and FECEP, led by middle class pastors, rejected the application. Membership of the IURD with its high degree of public visibility and its "inappropriate" practices would 
undermine their project of creating the image of an appropriate, socially acceptable Pentecostalism.

Middle class Pentecostals deny the IURD the status of a Protestant church. Although they acknowledge that the Argentinean public - as well as the IURD itself - defines the IURD as a iglesia evangélica, middle class Pentecostals refuse to identify the IURD as a Protestant church. According to them, the IURD misrepresents Protestantism and thereby contributes to the bad reputation of Protestantism. Therefore, they refuse to define the church as Protestant. Instead of classifying it as a Protestant church, middle class respondents use the term sect - in opposition to the concept of true Protestantism - to describe the IURD. The term "sect" connotes an extremely negative concept. Remarkably, by applying the term "sect", middle class Pentecostals employ the anti-sect discourse, also frequently used against Pentecostalism among the general public. However, in contrast to the public anti-sect discourse, they distinguish between churches that are "truly" Protestant and "non-Protestant" sects that are described as manipulative and exploiting their members. IURD falls into the last category. Hence, middle class Pentecostals adopt the anti-sect discourse for their own purposes by realigning it to their ideas of appropriateness and drawing boundaries between appropriate and inappropriate types of Pentecostalism. To depreciate the religion of the inappropriate other as a sect is a way of relating to his/her inappropriateness by drawing a sharp boundary between the own religious belonging and the inappropriate religious choice of the other. Another way of relating to the inappropriate other is to deliver him/ her from his/her inappropriate characteristics and to convert the inappropriate into an appropriate human being.

\subsubsection{Civilizing the Inappropriate Other}

Among middle class Pentecostals, one can observe efforts to convert the inappropriate other into an appropriate other. Some middle class Pentecostals engage in transmitting their cultural representations of the appropriate to lower class Pentecostals. They endeavor to civilize the inappropriate other who represents the disliked "culture of poverty".

An example of these attempts is Pastor Victor from AC. If a participant speaks in tongues during the church service, Pastor Victor explains to the participant after the service that speaking in tongues is not welcomed in AC. Pastor Victor strives to implement a more "appropriate", socially acceptable religious style among church members. Despite frequent references to the "liberty of expression" pastors of middle class congregations seek to discourage "inappropriate" practices among their members. Participants who cross the limits of the appropriate are asked to modify their behavior. However, not only 
pastors but also members are involved in these attempts to re-educate and amend inappropriate others. One example, Carlos, is an upper middle class architect who, during his free time, works on evangelization projects with prisoners. On a trip to one of these prisons he explained to me that he asks prisoners to speak properly in his presence. Carlos asks them to articulate in an appropriate form of Spanish because he supposes that their adaptation to an "appropriate" use of language will assist them in apprehending appropriate culture. This example illustrates that the culture of the other is not only perceived as inappropriate but that middle class Pentecostals also engage in reeducating the "popular masses".

Another example of these attempts at (re)education is the church Buenas Nuevas. Despite being located close to a slum, the congregation is influenced by the middle class. The church, committed to helping the "poor" runs social programs in the slum. Buenas Nuevas offers a specific church service at night with which the congregation tries to attract people from the slum. One of its pastors states that they want to discourage the "mentality of poverty". Although he claims that he dislikes the noisy style of Pentecostalism, he argues that the change of mentality is not so much related to the style of religious practice as it is to the education and culture of "the poor". While describing his church, he explains the ambitions of the congregation:

I've tried, we've tried to do our best, because, by doing our best, professionals and other people like that feel comfortable. But that isn't the objective, because we work very hard specifically with the poorest and least educated people in the area, and it seems that, to show them - we push the idea of personal improvement, we try to show people that there are other ways to live, to encourage them to appreciate other ways of life, (...) to get them out of the poverty mentality, because it's not only about poverty but also about the mentality, a mentality of dependence, and breaking away from this mindset is a big challenge, (...) So when we do things this way, it's because we want to change this mindset (...) we aim for excellence, always working toward levels of quality, always demonstrating that there are different ways to live.

INTERVIEW PASTOR RICARDO

The lower class is associated with a mentality of poverty that must be eradicated. This mentality of poverty that reigns in Argentina's slums and lower class neighborhoods is described as a mentality of dependency that deprives its hosts of a sense of autonomy and excellence. Even individuals with good earnings keep living in the misery of the Villa, despite having the economic 
means to leave the area. The pastor regards his work with the poor as a way of spurring cultural change and diminishing the mentality of poverty among the "culturally" poor. The objective of these efforts is to (re)educate lower class Pentecostals according to some of the middle class representations. Buenas Nuevas aims to convert the "uneducated" slum dwellers into middle class individuals committed to middle class representations: being educated, autonomous, and pursuing excellence. From this perspective, middle class Pentecostalism becomes an acculturation institution promoting "appropriate" culture among the "inappropriate".

Middle class Pentecostals not only adapt their own style to middle class representations, they also seek to spread "decent" culture among those social sectors that are historically conceived of as forming the mainstay of inappropriate culture. There are direct analogies to what Adamovsky describes as the general tendency of the middle class and elite to perceive the "popular masses" as lacking appropriate culture. ${ }^{14}$ The "popular masses" are portrayed as culturally maladapted and their material situation is traced back to this lack of cultural adaptation. Based on this perception, the middle class feels the need to reeducate these sectors according to the "cultivated" standards of middle class culture. Thus, the middle class aims for a re-education of the inappropriate others by training them in appropriate culture - the "white", "European" middle class culture. These efforts have their early roots in the civilization project of Argentina's founding fathers, as has been described in the fourth chapter.

The efforts to convert the "inappropriate slum dwellers" into respectable citizens do not necessarily undermine the symbolic class boundaries. In contrast, they even seem to strengthen these boundaries. The attempts at "civilization" aim to set the middle class representations of the appropriate as a general norm, as a shared hierarchy of appropriateness to which Pentecostals of all social classes should be committed. It is the attempt to convey to the inappropriate others that their way of being is less valuable than the way of being proposed by middle class Pentecostals. ${ }^{15}$ However, the creation of such a shared hierarchy of values faces serious limitations and may only partially succeed.

\footnotetext{
14 Adamovsky 2009.

15 By "civilizing" the inappropriate others, these actors try to impose their representations of appropriateness and their form of Pentecostalism as the legitimate standards by which other actors are expected to evaluate their practices. See also Bourdieu 1982: 136-142, 149-150; Bourdieu 1989b.
} 
The middle class representations of appropriateness are not exclusively bound to individuals who are "objectively" located in a middle class position. ${ }^{16}$ In some cases, middle class representations are adopted by actors, "objectively" situated in a lower class position. Therefore, among lower class Pentecostals one may also find critical voices with regard to some of the "exaggerated" characteristics of Pentecostalism and a tendency towards a more appropriate type of Pentecostalism. Consequently, the taste for a suitable style of Pentecostalism is mainly, but not exclusively, a middle class taste. To some extent, parts of the lower class commit themselves to an appropriate style of Pentecostalism. Nevertheless, other sections of the lower class adapt only very marginally - if at all - to the middle class standards of "appropriate" culture. Many Pentecostal churches favor a powerful, rather unadapted style of Pentecostalism. They appear not to care as much as middle class Pentecostals about the social acceptability of their religious practice. ${ }^{17}$ Consequently, the religious culture of lower classes is not a dominated culture, as has been also suggested by researchers like David Lehman, Eloisa Martin, and Pablo Semán. ${ }^{18}$ The lower class appears to evolve its religious culture autonomously. Sometimes its religious culture may even assume the form of a critical response to dominant cultural tenets. This autonomy implies that lower class Pentecostals may selectively adopt concepts and expressions from the middle class style of Pentecostalism and adjust them to their own logic.

\subsubsection{Remaining Deviations}

Although Pentecostals have undertaken considerable efforts to draw boundaries in opposition to "inappropriate" Pentecostalism and to develop a more appropriate style of Pentecostalism, the deviations that were at the origins of these endeavors do not completely disappear. Even in its more acceptable disguise, Pentecostalism remains a movement attached to popular religion and therefore alien to the representations of the middle class.

16 The middle class discourse has established itself over the course of history as the legitimate view in Argentinean society and has been adopted by parts of the lower class. See, for instance, Adamovsky 2009.

17 Interesting examples for this tendency are two lower class members of the middle class church AC. Although they have a positive opinion of AC, they prefer more expressive styles. In contrast to middle class interviewees from AC they showed no rejection of exorcisms and strong spiritual manifestations during church services and even claimed that it would be favorable for the congregation to integrate these practices into the church service. See Interview Simón Part 2; Interview Andrés.

18 See Lehmann 1996; Martin 2009; Semán 2000, 2001. 
Despite the attempts to adopt more appropriate styles and tastes, deviations continue to exist. This, for instance, is illustrated by the fact that even in highly adapted churches like AC, the religious practice is still perceived as strange by middle class outsiders. Alberto, for instance, explained that he experienced the practice of AC as very strange during his first visits to the church. Another example is Laura, who is afraid of facing embarrassment when friends pay a visit to an AC church service. Hence, even churches like AC do not necessarily fit well with what is regarded as appropriate by non-Pentecostal middle class actors. Despite the efforts undertaken to adapt Pentecostalism, there seem to remain deviations based on a general conflict between "what Pentecostalism is" and "what the middle class seeks to represent".

The boundaries middle class Pentecostals draw are not of an absolute nature. They refer to nuances of style. A full adaptation to middle class representations would imply a withdrawal from Pentecostalism, since essential religious beliefs of Pentecostalism such as, for instance, the belief in supernatural interventions in daily life, are unsuitable for the aspiration of becoming a secularized and rational "European" middle class. Staying loyal to their beliefs, they remain Pentecostals, but try to render the public expression of these beliefs into something socially acceptable. Although this endeavor may drive them to assume less expressive and emotional forms of Pentecostalism, middle class Pentecostalism is still an emotional and expressive form of religion. Deviations continue to exist. In some cases they even constitute deviations from the "more" appropriate style of Pentecostalism, as the case of Iglesia Peniel illustrates.

Iglesia Peniel is a Pentecostal church with a high proportion of lower middle and middle middle class members, and is located in a middle class neighborhood. The congregation is a rather closed community which visitors may only enter with a previous invitation from members or the pastor. During church services the church portal is guarded by doorkeepers who ask unknown visitors trying to enter the church about their business with the church. While the general style of the service is calm and resembles that of other middle class churches, there is a specific moment that sometimes occurs at the beginning of the service. This moment provides a context that allows members to express their emotions. It starts at the end of the musical praise: while the music plays and a large part of the congregation stands in front of the pulpit, individual members go up to the stage and declare their problems. The practice is conducted in a highly emotional atmosphere: the individual on the stage may shout, cry and tremble. However, after this moment, the sermon 
begins and the atmosphere becomes totally quiet. None of the members shout "Gloria a Dios" or other expressions. The first part of the church service creates a specific space for the expression of emotions, while the rest of the church service is dominated by a style that one also finds in other middle class churches. According to members of the church, this moment happens without planning and only very rarely, like when members feel the need to express their grievances. The existence of this practice appears to be encouraged by the fact that Iglesia Peniel is a rather closed community and perceived by members as providing a more intimate space than other churches. In this space, members feel a possibility to express emotions that they would otherwise only express in private.

The case of Iglesia Peniel demonstrates that churches may develop individual strategies for negotiating the (in)appropriatenessof Pentecostalism. This negotiation can sometimes result in a high degree of conformity as in the case of $\mathrm{AC}$, and in other cases integrate some rather "inappropriate" elements.

Being "inappropriate" leads to a renegotiation process involving continuous efforts to lessen and conceal the deviations and draw boundaries in opposition to the inappropriate. Yet, this process consists also in maintaining the inappropriate religious identity and not melding fully into the appropriate. In order to maintain their religious identity, middle class Pentecostals must remain inappropriate. Therefore, the boundary work remains incomplete. Boundary work helps to reduce the distance from the representations of the appropriate by drawing a symbolic boundary in opposition to "inappropriate Pentecostalism". But it does not fully eradicate the distance. Deviations from middle class representations are at the heart of Pentecostalism. These deviations can be partly camouflaged, but not removed without abandoning the Pentecostal identity. Hence, the only way to deal with the conflict is to practice the inappropriate appropriately.

\subsection{Summary}

This section addressed the origins and implications of the boundary work of middle class Pentecostalism. Historically, the evolution of middle class Pentecostalism is particularly spurred by three parties: (1) Pentecostal churches that increasingly assumed a middle class composition in their membership, (2) previously non-Pentecostal Protestants with strong middle class tendencies who experienced a charismatic renewal and finally became Pentecostal, and (3) Pentecostal congregations that restyle their Pentecostalism in order to 
recruit Argentina's middle class. These three tendencies culminate in a similar tendency towards a more appropriate Pentecostalism, a Pentecostalism which is more compatible with middle class representations. Nevertheless, this Pentecostalism is not a pure middle class phenomenon. Also lower classes may feel attracted to this socially more adapted and sober type of Pentecostalism.

Particularly middle class Pentecostals appear as fervent promoters of this tendency towards a more appropriate Pentecostalism. Risking stigmatization from their peers, they have a vital interest in creating and stabilizing a socially more acceptable type of Pentecostalism that fit better with their class representations. Drawing boundaries in opposition to the inappropriate attributes of Pentecostalism, they not only strive for a more appropriate form of Pentecostalism, but also distinguish themselves from an "inappropriate other" who is dedicated to an "inappropriate" type of Pentecostalism. The boundary work involves the (re)production of the imaginary of this inappropriate other, from which decent middle class Pentecostals seek distinction. This other is usually embodied by Pentecostals who practice their faith in the "untidy" churches of the poor conurbano; in other words: lower class Pentecostals. The example of the IURD illustrates the construction and stigmatization of the inappropriate other. The church is portrayed as a sect that moves beyond the borders of what is defined as "evangelical" and "Pentecostal". However, the boundary work of middle class Pentecostals sometimes even extends farther than only stigmatizing the inappropriate other. The most illustrative and paradoxical manifestation of the boundary work is its civilization efforts. Middle class Pentecostals attempt to civilize the "uncivilized" inappropriate others by training them in appropriate middle class culture and thereby seek to establish shared standards of appropriateness among Pentecostals. In summary, two typical techniques of relating to the inappropriate other are: (a) the depreciation of his/her religion as a sect and (b) his/her re-education and transformation into an "appropriate human being".

Despite the efforts to civilize Pentecostalism and to create a more appropriate type of Pentecostalism, the boundary work described in this chapter does not lead to a total dissolution of the tensions within middle class representations. Inappropriateness remains. Middle class congregations and Pentecostals continue to deviate to different degrees from their class representations. Boundary work helps to reduce tensions by performing the inappropriate in a more appropriate way, but it does not eliminate them. 